\title{
Doctors disappointed by income sprinkling changes
}

Cite as: CMAJ 2018 January 15;190:E62-3. doi: 10.1503/cmaj.106-5546

Posted on cmajnews.com on Dec. 19, 2017.

$\mathbf{T}$ he federal government has announced changes to its plan for curbing "income sprinkling," a strategy used by many doctors to reduce their taxes by diverting income through a corporation to family members who are taxed at lower rates.

The changes come after intense backlash from small business owners, including physicians, who in some provinces won the right to use these strategies in lieu of other benefits. However, critics say the new tweaks don't go far enough to address their concerns. Meanwhile, Conservative senators want the entire reform project delayed or scrapped.

Under the new proposal, the government will allow small business owners to split income with certain family members, including:

- Their spouse, so long as the business owner contributed meaningfully to the company and is over age 65;

- Adults over age 18 who worked in the business at least 20 hours per week or 1000 hours per year; and

- Adults over age 25 who own at least $10 \%$ of a company that earns less than $90 \%$ of its income from providing services and is not a professional corporation.

Family members who don't pass these "bright-line tests" will face a "reasonableness test" by the Canada Revenue Agency to determine whether they make legiti- mate contributions to the business. The new rules will apply to the 2018 tax year.

"This is part of our goal of making the tax system fair," Finance Minister Bill Morneau told reporters. Business owners
Only $5 \%$ of small business families see substantial savings from income sprinkling, with those earning more than $\$ 216,000$ per year receiving about half of the tax benefit. Small businesses in the

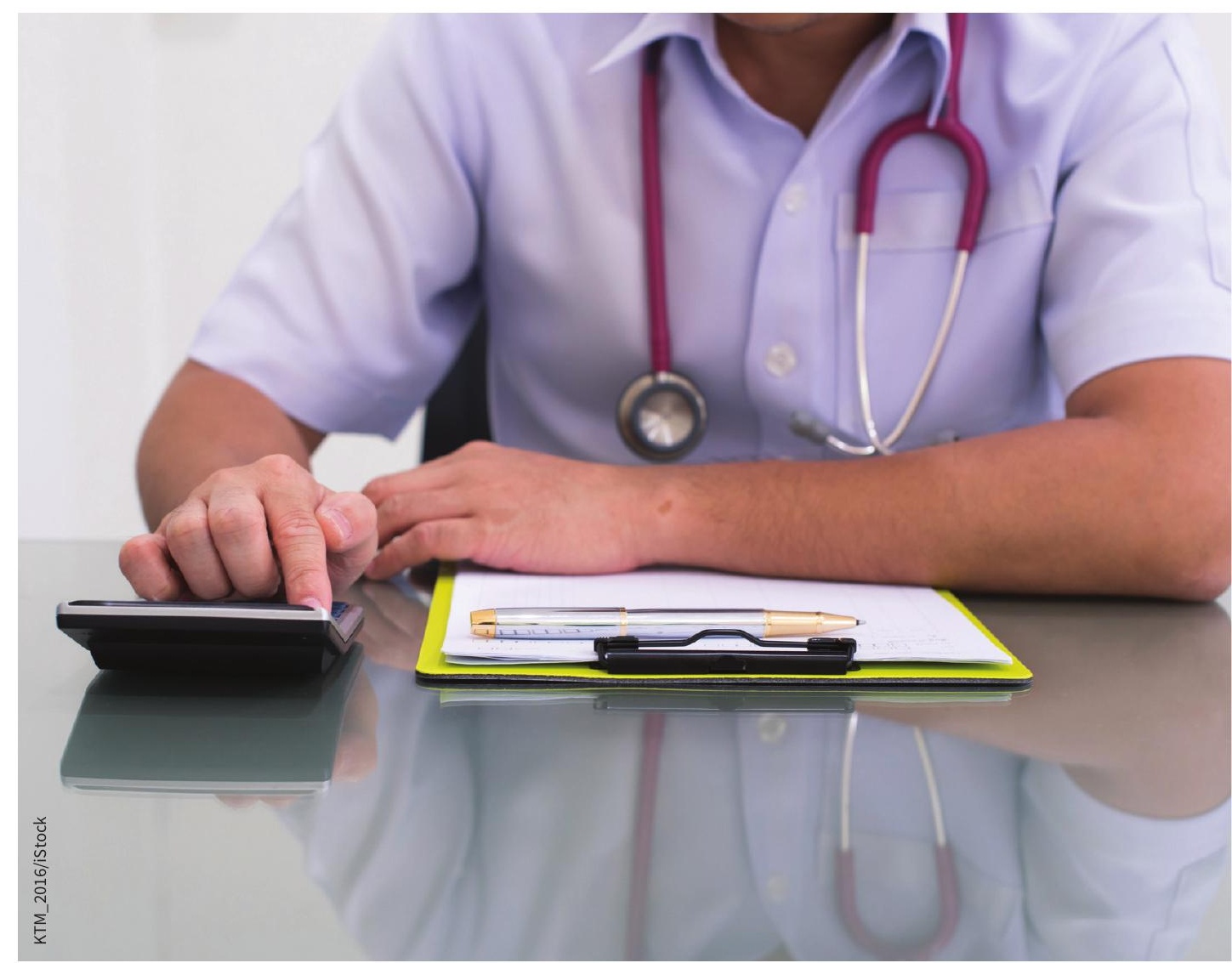

The government announced new exemptions to its income sprinkling rules, but doctors remain critical of the reforms. "have to show the amount of revenue they're passing to their spouse or children is reasonable." However, Morneau also stressed that $97 \%$ of small businesses will experience "absolutely no change in their situation." health sector, including doctors' practices, were most likely to benefit from income splitting and are therefore more likely to face a financial hit under the new rules.

Doctors remain very concerned with the unintended consequences of the tax 
changes, said Dr. Laurent Marcoux, president of the Canadian Medical Association (CMA). "A predictable and stable environment is critical to promote thriving medical practices."

Spouses are integral to the risk and development of business enterprises, including medical practices, Marcoux argued. To that end, doctors called for a full exemption for spouses from the new income sprinkling rules. "The CMA is disappointed that those recommendations were not adopted," Marcoux said.

He also cited concerns about the subjectivity and administrative burden of the proposed reasonableness test.
The Senate national finance committee echoed these concerns in a recent report, which urged the government to scrap its suite of tax reforms or at least delay implementation until 2019. "We are not convinced that the government has made a good case for its proposals," the report states.

The document highlights that the reasonableness test for income sprinkling could lead to arbitrary decisions by Revenue Canada bureaucrats because of the "difficult of understanding and complying with the rules."

The report also urges the government to undertake a comprehensive review of the entire tax code, regardless of whether it goes ahead with the proposed small business tax reforms.

According to Conservative Senator Percy Mockler, the report was backed by a majority of the committee, which is comprised of five Conservatives, five Independents and two Liberals.

However, Morneau noted the document was not produced unanimously and two Trudeau-appointed Independent senators indicated that they did not support the recommendations, raising doubts about partisan bias.

Lauren Vogel, CMAJ 